\title{
FOSSILS OF PRECAMBRIAN AGE FROM SOUTH-WEST GREENLAND
}

\author{
K. Raunsgaard Pedersen
}

In the Ketilidian fold belt of South-West Greenland some areas are only little metamorphosed and have been shown to contain macroscopic and microscopic fossil structures the age of which must be $1700-2000 \mathrm{~m} . \mathrm{y}$. (Raunsgaard Pedersen, 1966 and 1967; Bondesen, Raunsgaard Pedersen and Jфrgensen, 1967).

In the summer of 1967 a new search for macroscopic fossil structures was carried out together with the collecting of samples for further micropalaeontological investigations. The areas investigated were southern Grænseland, north-east of Ivigtut, and the Arsuk $\phi$ area south-west of Ivigtut.

In southern Grænseland tube-formed fossil structures like those found last year in the central part of Grænseland (Raunsgaard Pedersen, 1966) were found in many localities. The finds are all from a yellow dolomite just above the conglomerate in the basal layers of the Ketilidian succession. These fossil structures have now been found in most of the areas where the basal layers are exposed. In southernmost Grænseland near Arsuk Bræ the presence of these fossil structures and the lithology suggest that a part of the succession previously mapped as Grænses $\varnothing$ Formation should be referred to the Lower Zig Zag Land Formation.

A previously-described macrospherical structure (Bondesen, Raunsgaard Pedersen and Jørgensen, 1967, p. 28) was found in some localities in southern Grænseland. Like the first finds of this structure, the new finds are from the lower part of the Zig Zag Land Formation. These new finds, which are better preserved, make it very probable that the structures are of organic origin.

Another type of macroscopic structure of possible organic origin was found in great numbers in the upper part of the Ketilidian series in the Rendesten Formation near Rendestenen lake. It is a 
globular structure about 3-4 $\mathrm{mm}$ in diameter.

Vallenia erlingi Raunsgaard Pedersen, which was described from the northern Grænseland area where it is found in the upper part of the Grænses $\phi$ Formation, was not found in the Grænses $\phi$ Formation of southern Grænseland where this formation shows a slightly different facies development from the northern area. However, Vallenia was found very well preserved in a new locality in northernmost Grænseland, near Sioralik glacier, in the same stratigraphical level as the former finds.

A thick succession of Ketilidian supracrustal rocks is preserved in the Arsuk basin, which includes the localities Taylors Havn, Arsuk Stor $\varnothing$ and Arsuk $\varnothing$. These are separated from the Grænseland belt by a wide area of pre-Ketilidian gneisses, but the different formations in the Arsuk basin have been correlated on lithostratigraphical grounds with the formations in Grænseland. The grade of metamorphism in the Arsuk basin is however somewhat higher than in Grænseland. It might be expected that fossil structures are also to be found in the Arsuk basin and now material suitable for micropalaeontological investigations has been collected here. These rocks, however, yielded no macroscopic structures of obvious organic origin.

Work on the macroscopic and microscopic structures from Grænseland has been continued together with analysis of the material for organic compounds. The organo-chemical investigations have shown the presence of many compounds strongly indicative of organic activity during the time of Ketilidian sedimentation (Raunsgaard Pedersen and Lam, in press; Lam and Raunsgaard Pedersen, in press).

References

Bondesen, E., Pedersen, K. Raunsgaard and Jørgensen, O. (1967) Precambrian organisms and the isotopic composition of organic remains in the Ketilidian of South-West Greenland. Medd. Grønland, Bd. 164, Nr. 4. 
Lam, J. and Pedersen, K. Raunsgaard (in press) Precambrian organic compounds from the Ketilidian of South-West Greenland II. Medd. Grønland, Bd. 185, Nr。6. Pedersen, K. Raunsgaard (1966) Precambrian fossils from the Ketilidian of South-West Greenland. Rapp. Grфnlands geol. Unders., Nr. 11, 40-41.

Pedersen, K. Raunsgaard (1967) Nogle prækambriske fossilër fra Vestgrønland. Medd. dansk geol. Foren., Bd. 16, 195-196. Pedersen, K. Raunsgaard and Lam, J. (in press) Precambrian organic compounds from the Ketilidian of South-West Greenland I. Medd. Grфnland, Bd. 185, Nr. 5.

\author{
PROSPECTING INSTRUMENTS USED IN THE SURVEY \\ OF URANIUM-THORIUM AND BERYLLIUM IN \\ THE ILIMAUSSAQ INTRUSION, SOUTH GREENLAND
}

\title{
Leif Lфvborg and John Hansen
}

A series of detailed investigations initiated in the llímaussaq alkaline intrusion in 1964 comprises petrological, geochemical and mineralogical examinations carried out by the Petrological Institute of the University of Copenhagen and the Danish Atomic Energy Commission's Research Establishment at Ris $\phi$, under the auspices of the Geological Survey of Greenland.

As uranium-thorium and niobium mineralizations are most common in the lujavrites of the Kvanefjeld area and beryllium and niobium mineralizations are common on the Taseq slope in the northwestern part of the intrusion, the work so far has been concentrated in these areas. The first part of the detailed mapping of the Kvane- 